TITLE:

\title{
Expression of $\mathrm{Nedd} 2 / \mathrm{ICH}-$ 1 (caspase-2)in the developing ratretina(Abstract_要旨)
}

$\operatorname{AUTHOR}(\mathrm{S})$ :

Kojima, Masahiro

\section{CITATION:}

Kojima, Masahiro. Expression of Nedd2/ICH-1(caspase-2)in the developing ratretina. 京都 大学, 1999, 博士(医学)

ISSUE DATE:

1999-03-23

URL:

http://hdl.handle.net/2433/181729

RIGHT: 


\section{【244】}

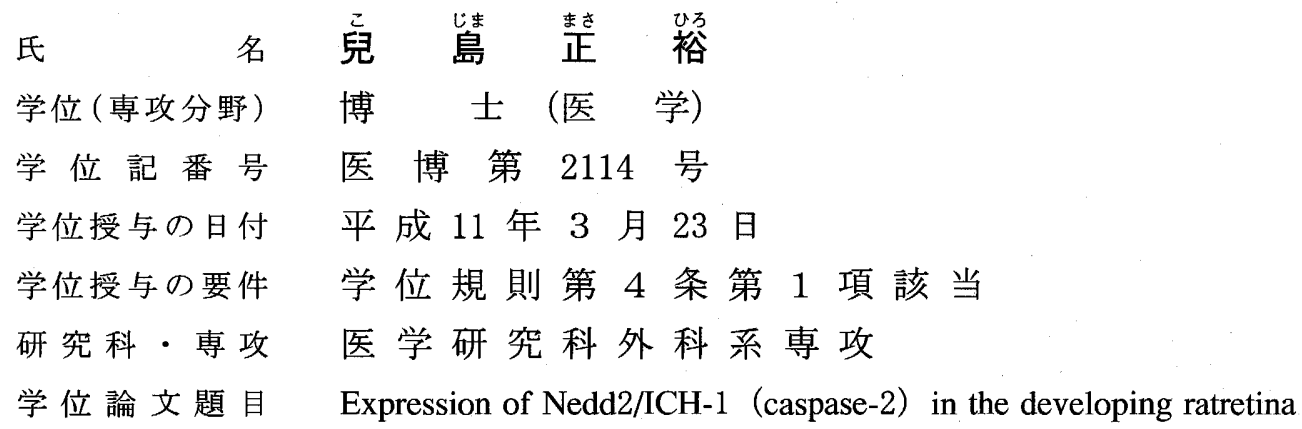

（発達過程のラット網膜における Nedd2/ICH-1（caspase-2）の発現） (主査)

論文調查委員 教 授影山龍一郎 教授 本田孔士教授橋本信夫

論文 内 容 の 要旨

網膜の発達過程における細胞死は種々の所見からプログラム細胞死（アポトーシス）であることが知られている。プログ ラム細胞死の分子レベルでのメカニズムの主役として，CED 3/CEファミリーに属する protease（caspase）が同定されて いるが，この中でもNedd $2 / \mathrm{ICH}-1$ (caspase- 2 ) は中枢神経のプログラム細胞死に重要な役割を果たしていると言われて いる。今回我々は発達過程のラット網膜でのNedd 2 の発現と局在を中心に検索した。

胎生17，19日齢，生後 $0 ， 3 ， 5 ， 7 ， 14 ， 21 ， 28$ 日齢のウィスター系ラット網膜を対象に, murine ICE, murine Nedd 2 , human CPP32の各プローブを使用したノザンブロッティングを行い, mRNAの発現量の変化を調べた。またNedd 2 のス プライシングによってできる 2 種類のNedd 2 mRNAの鑑別が可能なプライマーを使用して，RT－PCR法によるRNAマッ ピングを行い, さらに免疫染色法によりラット網膜でのNedd 2 の局在，を検索した。

ノザンブロッティングにて，ICEmRNAは検索したラット網膜の発達過程の期間を通してごく僅かな発現が見られるのみ であった。それに対し, Nedd 2, CPP32 mRNAの発現量は胎生後期から誕生に至るまでの間著明に多く，生後は減少して いた。スプライシングにて 2 種類のNedd 2 が発現するが，プログラム細胞死を抑制すると考えられているNedd 2 \&は胎生 期には発現量は少なく，生後次第に増加していた。またニューロンの分化の過程でNedd 2 。発現が誘導されることも同時 に示した。

神経節細胞層は胎生19齢には神経芽細胞層から分離し, 生後 3 日齢には層として完全に分離する。この間, Hoechst染色 で観察されたように，神経節細胞の半数がプログラム細胞死を引き起こす。この時期の神経節細胞層では，ほとんど全ての 細胞が免疫染色法にてNedd 2 が陽性である一方, Hoechst染色で示されたアポトーシス発現細胞ではNedd 2 が陰性であっ た。さらに生後 3 日齢では神経芽細胞層内の層も分離して明らかになり, 神経芽細胞層内にもアポトーシス発現細胞が散見 されるようになる。免疫染色では分離する各層によって発現するNedd 2 の免疫染色性の強さに差があった。生後14日齢に は網膜内の全ての層が明らかとなってくるが, アポトーシスとNedd 2 発現細胞はほとんど見られなくなってくる。

Nedd 2 は同じプログラム細胞死の過程内で, CPP32の上流に位置すると言われる。CPP32が網膜細胞のプログラム細胞 死の発現に関与していることが示唆されていることと考えあわせると, Nedd 2, CPP32 mRNAが発達綱膜内で同じパター ンの発現を示すことは興味深い。しかし，Nedd 2 mRNAの発現が生後 3 日齢には減少が始まることは，実際のプログラム 細胞死の発生の時期より学すぎる様に思われる。また免疫染色法では生後 3 日齢には末だ細胞内のNedd 2 発現が認めら れる。これらの矛盾を説明するためには，今後更なる研究が要求される。

Nedd 2、はプログラム細胞死に対して抑制的に働くと言われ，誕生までの間に発現が少ないことはNedd 2 がラット網膜 の細胞のプログラム細胞死の調節に関与していることを示唆している。また生後このNedd $2{ }_{\mathrm{s}}$ の発現量が増加し，生後14日 歯にはNedd 2 の発現と同レベルに至ることは，他の報告ともあわせ考えて，この蛋白が神経細胞の成熟化にも寄与してい るものと考えられる。 


\section{論 文 審 査 の 結 果 の 要 旨}

近年, 組織の発達過程で起こるプログラム細胞死は, カスパーゼ遺伝子群によって支配されていることが明らかとなった。 この遺伝子群の一員であるNedd 2 は発達過程の中枢神経系で著明に発現することが知られているが，そのプログラム細胞 死に対する役割については未知のことが多い。今回，発達過程の網膜でプログラム細胞死にNedd 2 が果たしている役割を 解明することを目的に，ノザンブロッティング，リバースPCR法，免疫染色法を使用して，ラット網膜におけるNedd 2 の 発現や局在の変化を検索した。

Nedd 2 mRNAは胎生期のラット網膜で著明に発現し, 生後その発現は減少していた。この変化は, 同じカスパーゼ遺伝 子群に属するCPP32mRNAと同じ発現パターンを示していた。CPP32は中枢神経の発達に関与することが知られており， Nedd 2 とCPP32がプログラム細胞死の過程において，同じ経路内で作用している可能性が示唆された。

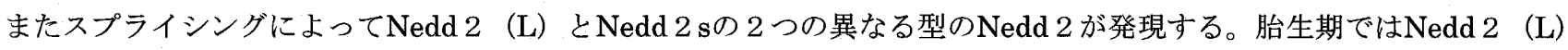
が著明に優位な発現を示していたが, 生後Nedd 2 。発現が次第に増加し, 生後14日齢には両者の発現量はほぼ同程度となっ

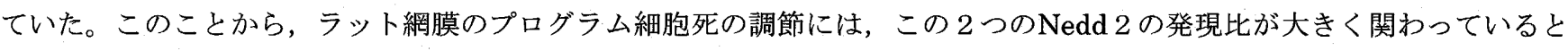
考えられた。

以上の研究は, 網膜の発達過程のプログラム細胞死に対するカスパーゼの果たす役割の解明に貢献し, 中枢神経系の発生 機序の知識に寄与するところが多い。

したがって, 本論文は博士（医学）の学位論文として価値あるものと認める。

なお，本学位授与申請者は，平成11年 2 月 9 日実施の論文内容とそれに関連した諮問を受け，合格と認められたものであ る。 